\title{
Pressure ulcer prevention and treatment: use of prophylactic dressings
}

\author{
This article was published in the following Dove Press journal: \\ Chronic Wound Care Management and Research \\ II October 2016 \\ Number of times this article has been viewed
}

\author{
Kathleen Reid' \\ Elizabeth A Ayello² \\ Afsaneh Alavi ${ }^{3}$ \\ 'Department of Nursing Practice \\ and Education, Bridgepoint Active \\ Healthcare, Toronto, Canada; ${ }^{2}$ School \\ of Nursing, Excelsior College, Albany, \\ NY, USA; ${ }^{3}$ Department of Medicine, \\ University of Toronto, Toronto, \\ Canada
}

\begin{abstract}
The management of pressure ulcers is challenging for health care providers across disciplines. Pressure ulcers have significant impact on emotional and physical wellbeing, quality of life, and health care costs. The use of wound dressings could be an important and cost-effective strategy in preventing pressure ulcers. The main types of dressings that are examined for this purpose in the literature are foam, hydrocolloid, and films. Some small studies have shown a preventative role for sacral dressings with low-shear backings, though they raise concerns about over-hydration of the skin. Further research demonstrates the application of barrier films over bony prominences to have a prophylactic effect; however, adhesive dressings can also contribute to shearing forces on the skin. There is a vast body of research that examines the use of dressings to prevent pressure ulcers; however, there is limited high-level evidence, such as randomized control trials. A 2013 Cochrane review indicated that there is a paucity of high-level evidence to support the prophylactic use of dressings to prevent pressure ulcers; this paper will examine the emerging literature and consider its relevance to pressure ulcer prevention protocols.
\end{abstract}

Keywords: quality of life, hydrocolloid dressing, topical agent

\section{Introduction}

Pressure ulcers are a major cause of mortality, morbidity, patient suffering, and cost on the health care system worldwide. The management of pressure ulcers is a compounding challenge to health care professionals across disciplines. Individuals who acquire pressure ulcers often require long-term interventions, representing a large economic burden to the health care system. It has been estimated that in Australia, these injuries increase the length of hospital stay and subsequently incur \$285 million in cost annually. ${ }^{1}$ Since 2008, the Centers for Medicare and Medicaid Services no longer reimburses American hospitals at a higher rate for any pressure ulcer that occurs during a patient's hospitalization, which provides a strong financial stimulus for pressure ulcer prevention protocols to be implemented. ${ }^{2}$ Indeed, the profound impact of pressure ulcers on the emotional, physical, mental, and social domains of life has been shown in different studies. ${ }^{3}$ Current management strategies target pressure-relieving surfaces: patient repositioning, nutritional support, and application of protective dressings to prevent pressure injuries. Dressings are accessible and easily implemented devices; however, they can also contribute to high health care costs. Therefore, it is important to evaluate their efficacy.

Although various topical agents and protective dressings have been historically and anecdotally used as preventative strategies to maintain healthy skin, conclusions of the 2013 Cochrane review do not support this practice. ${ }^{4}$ Nonetheless, the application of ar
hereby accept the Terms. Non-commercial uses of the work are permitted without any further permission from Dove Medical Press Limited, provided the work is properly attributed. For permission for commercial use of this work, please see paragraphs 4.2 and 5 of our Terms (https://www.dovepress.com/terms.php). 
dressings and other topical products is prevalent in guidelines regarding pressure ulcer prevention. ${ }^{5,6}$

\section{Review of the classification and risk factors}

A pressure ulcer is defined as: "localized injury to the skin and/or underlying tissue usually over a bony prominence, as a result of pressure, or pressure in combination with shear." A combination of shear and pressure leads to a large magnitude of tissue injuries near bony prominences. A shearing force acts parallel to the skin surface while the base is stable. Shearing forces occur when a patient cannot support their own weight and maintain postural alignment. Shearing forces significantly decrease the threshold of tissue damage. Shearing force is a factor when a person slides or the angle of the bed or chair changes. The term "shear" describes both shear stress and force. ${ }^{7}$ Friction is the force due to resistance between the motions of two objects when they are touching. ${ }^{7}$ Another influential factor would be skin $\mathrm{pH}$ level. Skin integrity is optimized in the $\mathrm{pH}$ of $4-6.8 .^{8}$

Studies have shown that the majority of hospital-acquired pressure injuries had an emergency stay of more than 2 hours. ${ }^{9}, 10$ This study emphasizes the role of preventative measures starting from emergency department admissions. The type of fabric next to the skin and lack of moisture affect the amount of shear and pressure and subsequently tissue damage. ${ }^{7,10}$

A pressure ulcer can be diagnosed at any stage; however, initially (stage I) it may appear as a localized area of nonblanching erythematous skin, often over a bony prominence or adjacent to a medical device (ie, a nasogastric feeding tube). However, pressure ulcers caused by medical devices on mucous membranes are not staged using the National Pressure Ulcer Advisory Panel (NPUAP)/European Pressure Ulcer Advisory Panel (EPUAP)/Pan Pacific Pressure Injury Alliance (PPPIA) staging system as analogous tissue comparisons of the mucous membrane to the skin cannot be made. ${ }^{6}$ Black et al have described the use of dressings to prevent pressure ulcers from medical devices. ${ }^{11}$ The diagnosis can be confirmed if the lesion resolves when pressure is relieved.

\section{Prophylactic role of dressings}

A wide range of dressings has been studied for the prevention of pressure ulcers. The three main dressings that are primarily reviewed in the literature are:

- Film dressings

- Hydrocolloid dressings

- Foam dressings
In the intact skin of category/stage I pressure ulcers, hydrocolloids and films are indicated in various guidelines. Emollients and film-forming barriers have been used to protect the skin from friction, shear, and moistureassociated damage. More recently, foams and absorptive dressings have been used in clinical trials. Aquacel ${ }^{\circledR}$ foam dressing has been used in a prospective evaluation of 42 patients (mean Braden score: 13.8) with a decrease in incidence of pressure ulcers in populations at risk from $4.3 \%$ to $1.8 \% .^{12}$ In this study, all patients had altered skin integrity; however, the use of topical agents prevented the injuries from progressing to full thickness. Philbin also reported seven patient case evaluations using the same dressing. ${ }^{13}$ Table 1 summarizes the evidence for the use of dressings for pressure ulcer prevention.

A 2013 Cochrane review concluded that there was insufficient randomized control trial evidence to support or refute the use of dressings, creams, or lotions to prevent pressure ulcers. ${ }^{4}$ Five clinical trials (940 patients) with potential bias, comparing topical agents with a placebo, were included. A risk ratio of 0.78 ( $95 \%$ confidence interval $0.47-1.31 ; P$-value 0.35 ) is indicative of no beneficial effect of topical agents overall. ${ }^{4}$

The same study reviewed four trials (561 patients) on the use of dressings over bony prominences and showed a reduced pressure ulcer incidence with a risk ratio of 0.21 (95\% confidence interval 0.09-0.51; $P$-value 0.0006$){ }^{4}$

Barrier films were found to have both a protective and treatment role in preventing skin breakdown in a very small study population. By applying an appropriate barrier film or cream, the product mimics the skin's natural function of protecting and moisturizing the skin underneath. This 95-patient study did not include a Braden score to assess pressure ulcer risk for inclusion in the study, however, most participants had a noted improvement in clinical risk for pressure ulcer development, such as skin maceration. It should be noted, however, that the particular barrier film and cream that were examined were provided by a third-party medical company potentially contributing to funding bias. ${ }^{14}$ In a study by Schafer et al, the concern regarding over-hydration of the skin by prophylactic dressings was raised, and so dressings with an absorptive structure were recommended. ${ }^{15}$ Doughty reminds us of the clinical importance for the accurate differential assessment of trunk wounds as a critical element for their effective management. ${ }^{16}$

\section{Silicone dressings to prevent pressure ulcers}

There is a growing amount of clinical evidence regarding the role of dressings to prevent pressure ulcers. In 2009, 
Table I Evidence for dressings to prevent pressure ulcers

\begin{tabular}{|c|c|c|c|}
\hline Study & Subjects & Type of dressings & Findings \\
\hline $\begin{array}{l}\text { Ohura et al }{ }^{24}(2008) \\
\text { Japan }\end{array}$ & $\begin{array}{l}\text { Porcine skin model:pressure } \\
\text { applied from a sensor and } \\
\text { measurements taken }\end{array}$ & $\begin{array}{l}\text { Five dressings in three categories } \\
\text { (foams, films, hydrocolloids) } \\
\text { evaluated versus a control of } \\
\text { no dressing }\end{array}$ & $\begin{array}{l}\text { All dressing materials reduced pressure } \\
\text { compared to the control group }\end{array}$ \\
\hline $\begin{array}{l}\text { Torra I Bou et } \mathrm{al}^{20} \\
\text { (2009) Spain }\end{array}$ & $\begin{array}{l}\text { I I I participants completed a study } \\
\text { from three long-term care facilities } \\
\text { and three home care programs }\end{array}$ & $\begin{array}{l}\text { Polyurethane foam dressing } \\
\text { to heel }\end{array}$ & $\begin{array}{l}\text { Significant reduction in heel pressure ulcers } \\
\text { with foam dressings. } \\
3.3 \% \text { in the foam dressing group developed } \\
\text { pressure ulcers compared to } 44 \% \text { in the } \\
\text { soffban/gauze group. }\end{array}$ \\
\hline $\begin{array}{l}\text { Brindle }{ }^{21}(2010) \\
\text { USA }\end{array}$ & $\begin{array}{l}4 I \text { high-risk patients from a total } \\
\text { of } 93 \text { patients in their surgical } \\
\text { cardiac ICU over } 3 \text { months }\end{array}$ & Silicone foam dressing to sacrum & $\begin{array}{l}\text { 0/4I patients developed a pressure ulcer } \\
\text { Three patients developed a pressure ulcer } \\
\text { after use of dressing was discontinued }\end{array}$ \\
\hline $\begin{array}{l}\text { Brindle and Wegelin }{ }^{22} \\
(2012) \text { USA }\end{array}$ & $\begin{array}{l}\text { Nonrandom designation of } \\
\text { I00 consecutive patients } \\
\text { in a cardiac surgical ICU }\end{array}$ & $\begin{array}{l}\text { Two groups: standard treatment } \\
\text { versus intervention group with } \\
\text { treatment of a foam dressing } \\
\text { to the sacrum }\end{array}$ & $\begin{array}{l}\text { Eight pressure ulcers developed in four of the } \\
35 \text { patients ( } 1 \text { I.7\%) in standard preventive } \\
\text { care group. } \\
\text { One pressure ulcer developed in the } 50 \\
\text { patients in the intervention group ( } 2.0 \%) \text { with } \\
\text { the silicone foam dressing. } \\
\text { No statistically significant difference between } \\
\text { the two groups; authors suggested that the } \\
\text { absence of statistical difference reflects a } \\
\text { type } 2 \text { error caused by insufficient power }\end{array}$ \\
\hline $\begin{array}{l}\text { Chaiken }^{17}(2012) \\
\text { USA }\end{array}$ & $\begin{array}{l}\text { Non-experimental prospective } \\
\text { study of ICU patients over } \\
35 \text { months. } \\
273 \text { patients in an ICU received } \\
\text { the intervention }\end{array}$ & $\begin{array}{l}\text { Compared prevalence rate } \\
\text { in ICU over } 35 \text { months before } \\
\text { and after care protocol changes } \\
\text { to include use of foam dressing } \\
\text { to the sacrum }\end{array}$ & $\begin{array}{l}\text { Previous prevalence rate: } 12.3 \% \text {. } \\
\text { Five patients developed sacral pressure } \\
\text { ulcers for a hospital-acquired pressure } \\
\text { ulcer incidence rate of } 1.8 \% \text { after routine } \\
\text { use of foam dressing applied to sacrum }\end{array}$ \\
\hline $\begin{array}{l}\text { Walsh et al }{ }^{18}(2012) \\
\text { USA }\end{array}$ & $\begin{array}{l}\text { 3-month data collection } \\
\text { on ICU patients }\end{array}$ & $\begin{array}{l}\text { Preventive application of foam } \\
\text { dressing to the sacrum }\end{array}$ & $\begin{array}{l}53 \text { ICU patients had pressure ulcers: } 12.5 \% \\
\text { incidence compared to three out of } 62 \\
\text { patients ( } 4.8 \%) \text { who developed pressure } \\
\text { ulcers after routine application of the foam } \\
\text { dressing became standard of care }\end{array}$ \\
\hline $\begin{array}{l}\text { Kiely }^{26}(2012) \\
\text { USA }\end{array}$ & $\begin{array}{l}\text { Pilot study of use of a silicone } \\
\text { foam in acute care }\end{array}$ & $\begin{array}{l}\text { Foam dressing applied to sacrum } \\
\text { of patients with Braden score }\end{array}$ & $\begin{array}{l}\text { Zero pressure ulcers with initiative of this } \\
\text { preventive protocol }\end{array}$ \\
\hline
\end{tabular}

of 18 or below to prevent skin breakdown

Application of silicone dressing to sacrum of high-risk patients from the emergency department transferred to the medical ward Silicone foam dressing applied to heel and sacral area

Australia

9 (2013)

Cubit et $\mathrm{al}^{23}(2013)$ Australia

Nonrandomized experimental 2-month period of time based on the Waterlow Pressure Ulcer RCT of patients in ED followed into ICU $(n=219)$ with prophylactic dressing used versus control group of no silicone dressing

Philbin et $\mathrm{al}^{12}(20 \mathrm{|})$ USA Case study of one hospitalized patient led to a prospective evaluation of 42 patients with Braden Scale scores of 18 or below

$\operatorname{Park}^{25}$ (2014)

South Korea
Nonrandomized comparison cohort study of 102 patients in two ICUs
Foam dressing applied to sacral area

52 in group with standard care plus silicone foam dressing and 50 in group with standard care with no foam dressing for prevention
One of the 52 patients developed a pressure ulcer (stage II)

Fewer sacral ( 2 versus $8, P=0.05$; heel pressure ulcers 5 versus $10, P=0.02$ ) and overall 7 versus $27, P=0.0002$

Preintervention rates ranged from $0 \%$ to $17.2 \%$ while post-implementation rates of pressure ulcers ranged from $0 \%$ to $5.2 \%$ with an average of $1.8 \%$

Subjects in silicone foam dressing group had significantly lower occurrence of pressure ulcers compared to patients in the control group ( $6 \%$ versus $\left.46 \%, \chi^{2}=21.722, P<0.00 I\right)$

Abbreviation: ICU, intensive care unit.

Torra I Bou et al reported a significant reduction in heel pressure ulcers in persons in long-term care facilities and home-care agencies when foam dressing rather than a protective heel bandage (Soffban and gauze) was used..$^{20}$
In this study, participants who received the gauze bandage had a $44 \%$ risk of developing a pressure ulcer compared with the $3.3 \%$ represented by the foam dressing. Bindle et al conducted some of the earliest studies using critically 
ill patients. ${ }^{21,22}$ In one of these observational studies, none of the 41 high-risk patients who had a silicone dressing prophylactically applied to their sacrum developed a pressure ulcer. In a follow-up nonrandomized study of 100 consecutive patients in the cardiac surgical intensive care unit, Brindle and Wegelin ${ }^{22}$ reported that four of the patients in the standardized care group developed pressure ulcers compared to one out of 50 patients in the intervention group that had a foam dressing prophylactically applied to the sacrum. ${ }^{22}$ A 2013 study by Cubit et al demonstrated that application of a protective sacral dressing with low-shear backing is a simple preventative strategy to reduce the risk of pressure ulcers. ${ }^{23}$ The results comparing the 51 patients in the interventional group to patients with similar demographics demonstrated that the control group was 5.4-times more likely to develop pressure ulcers. ${ }^{23}$ With this growing amount of evidence, the NPUAP/EPUAP/PPPIA included a recommendation in their 2014 Pressure Ulcer Guideline. It states "Consider applying a polyurethane foam dressing to bony prominences (eg, heels, sacrum) for the prevention of pressure ulcers in anatomical areas frequently subjected to friction and shear (strength of evidence B)."

\section{Conclusion}

Chronic pressure ulcers pose some complex challenges for patients that include excess drainage, odor, pain, decreased participation in activities of daily living, and increased need for caregiver and health care support. It is indisputable that appropriate use of dressings to treat pressure ulcers is an important dimension to enhancing a patient's quality of life.

The best management of pressure ulcers is prevention, through a variety of means, including nutritional support, proper supportive surfaces, frequent movement or turning, as well as the appropriate use of dressings.

There remains a gap in the literature surrounding the use of dressings and topical agents to prevent the development of pressure ulcers. While a fair amount of literature has been generated since the Cochrane review on this topic, study sizes are small mostly non-randomized in design. Stronger randomized control trials and case series are needed in order to support the guidelines in this area. Dressings certainly play a role in the treatment of pressure ulcers as part of a multifactorial treatment plan. Stronger evidence to support a particular type of dressing is needed.

\section{Disclosure}

The authors report no conflicts of interest in this work.

\section{References}

1. Graves N, Birrell FA, Whitby M. Modeling the economic losses from pressure ulcers among hospitalized patients in Australia. Wound Repair Regen. 2005; 13:462-467.

2. Centers for Medicare \& Medicaid Services Medicare Program. Proposed Changes to the Hospital Inpatient Prospective Payment Systems and Fiscal Year 2009 Rates. Proposed Additions to Hospital Acquired Conditions for Fiscal Year 2009. Available from: www.cms.hhs.gov/ apps $/$ media $/$ press $/$ factsheet.asp C Counter $=3042$ \&intNumPerPage $=10$ $\&$ checkDate $=\& \operatorname{checkKey}=\&$ srchType $=1 \&$ numDays $=3500 \&$ srchOpt $=0 \&$ srchData $=\&$ keywordType $=$ All $\&$ chkNewsType $=6 \&$ intPage $=\&$ sho wAll $=\&$ pYear $=\& y e a r=\&$ desc $=$ false $\&$ cboOrder $=$ date\#_ftn 1. Accessed September 14, 2014.

3. Spilsbury K, Nelson A, Cullum N, Iglesias C, Nixon J, Mason S. Pressure ulcers and their treatment and effects on quality of life: hospital inpatient perspectives. J Adv Nurs. 2007;57:494-504.

4. Moore ZE, Webster J. Dressings and topical agents for preventing pressure ulcers. Cochrane Database Syst Rev. 2013;8: CD009362.

5. Stansby G, Avital L, Jones K, Marsden G, Guideline Development Group. Prevention and management of pressure ulcers in primary and secondary care: summary of NICE guidance. BMJ. 2014;348:g2592.

6. Emily Haesler, editor. National Pressure Ulcer Advisory Panel, European Pressure Ulcer Advisory Panel and Pan Pacific Pressure Injury Alliance. Prevention and Treatment of Pressure Ulcers: Quick Reference Guide. Perth: Cambridge Media; 2014.

7. Kallman U, Lindgren M. Predictive validity of 4 risk assessment scales for prediction of pressure ulcer development in a hospital setting. Adv Skin Wound Care. 2014;27:70-76.

8. Beldon P. Problems encountered managing pressure ulceration of the sacrum. Br J Community Nurs. 2008;13:S6, S8, 10 passim.

9. Denby A, Rowlands A. Stop them at the door: should a pressure ulcer prevention protocol be implemented in the emergency department? $J$ Wound Ostomy Continence Nurs. 2010;37:35-38.

10. Smith A, McNichol LL, Amos MA, et al. A retrospective, nonrandomized, beforeand- after study of the effect of linens constructed of synthetic silk-like fabric on pressure ulcer incidence. Ostomy Wound Manage. 2013;59:28-30, 32-34.

11. Black J, Alves P, Brindle CT, et al. Use of wound dressings to enhance prevention of pressure ulcers caused by medical devices. Int Wound J. Epub July 1, 2013.

12. Philbin S, Shaw H, Walker M, Bishop S. The Role of New Foam Dressing Technology in Prevention of Skin Breakdown. Ostomy Wound Manage. 2013;59(4):8.

13. Philbin S. Pressure ulcer management using sodium carboxymethylcellulose hydrofiber ${ }^{\circledR}$ foam dressings. Ostomy Wound Manage. 2013;59: $10-12$.

14. Stephen-Haynes J. The role of barrier protection ain pressure ulcer prevention. Br J Nurs. 2013;22:S52, S54-S58.

15. Schafer P, Bewick-Sonntag C, Capri MG, Berardesca E. Physiological changes in skin barrier function in relation to occlusion level, exposure time and climatic conditions. Skin Pharmacol Appl Skin Physiol. 2002;15:7-19.

16. Doughty D. Differential assessment of trunk wounds: pressure ulceration versus incontinence associated dermatitis versus intertriginous dermatitis. Ostomy Wound Manage. 2012;58:20-22.

17. Chaiken N. Reduction of sacral pressure ulcers in the intensive care unit using a silicone border foam dressing. JWound Ostomy Continence Nurs. 2012;39:143-145.

18. Walsh NS, Blanck AW, Smith L, Cross M, Andersson L, Polito C. Use of a sacral silicone border foam dressing as one component of a pressure ulcer prevention program in an intensive care unit setting. J Wound Ostomy Continence Nurs. 2012;39:146-149.

19. Santamaria N, Gerdtz M, Sage S, et al. A randomised controlled trial of the effectiveness of soft silicone multi-layered foam dressings in the prevention of sacral and heel pressure ulcers in trauma and critically ill patients: the border trial. Int Wound J. Epub May 27, 2013. 
20. Torra I Bou JE, Rueda López J, Camañes G, et al. Preventing pressure ulcers on the heel: a Canadian cost study. Dermatol Nurs. 2009;21: 268-272.

21. Brindle CT. Outliers to the Braden Scale: Identifying high-risk ICU patients and the results of high-risk dressing use. World Council of Enterostomal Therapists Journal. 2010;30:1-8.

22. Brindle CT, Wegelin JA. Prophylactic dressing application to reduce pressure ulcer formation in cardiac surgery patients. J Wound Ostomy Continence Nurs. 2012;39:133-142.

23. Cubit K, McNally B, Lopez V. Taking the pressure off in the Emergency Department: evaluation of the prophylactic application of a low shear, soft silicon sacral dressing on high risk medical patients. Int Wound J. 2013;10:579-584.
24. Ohura T, Takahashi M, Ohura N Jr. Influence of external forces (pressure and shear force) on superficial layer and subcutis of porcine skin and effects of dressing materials: are dressing materials beneficial for reducing pressure and shear force in tissues? Wound Repair Regen. 2008;16:102-107.

25. Park KH. The effect of a silicone border foam dressing for prevention of pressure ulcers and incontinence-associated dermatitis in intensive care unit patients. J Wound Ostomy Continence Nurs. 2014;41:424-429.

26. Kiely C. Cultural transformation in pressure ulcer prevention and care. J Wound Ostomy Continence Nurs. 2012;39:443-446.

\section{Publish your work in this journal}

Chronic Wound Care Management and Research is an international, peer reviewed, open access, online journal publishing original research, reviews, editorials, and commentaries on the causes and management of chronic wounds and the major issues related to chronic wound management. Topics also include chronic wounds as comorbidities to other conditions, patient adherence to therapy, and the economic burden of chronic wounds. The manuscript management system is completely online and includes a very quick and fair peer review system, which is all easy to use. Visit http://www.dovepress.com/testimonials.php to read real quotes from published authors.

Submit your manuscript here: http://www.dovepress.com/chronic-wound-care-management-and-research-journal 